2020, Volume 14, International Conference Innovative Business Management \& Global Entrepreneurship (IBMAGE 2020), pages: 483-497 |

https://doi.org/10.18662/lumproc/ibmage2020/35

\section{Trends of \\ Convergence at Regional Level in European Union (EU-28)}

\section{Daniela ANTONESCU1}

${ }^{1}$ Institute of National Economy, Bucharest, Romania, daniela.antonescu25@gmail.com
Abstract: The objective regarding cohesion is achieved by means of a convergence process that assumes diminishing territorial inequalities between regions and territories. The cohesion process is not limited to the relatively poor regions, but aims also to more developed regions with the purpose of observing also the secondary effects for the entire EU (EC Report, 2013).

Identifying the convergence or divergence trends is one of the intensely argued topics by both the academic and the politicaldecisional environment. The theoretical point of view approach regarding convergence was accompanied by models meant to mitigate the requirements of assessing over given periods the evolution of territorial inequalities (between countries or regions). Identifying a process of convergence or divergence at regional level is a widely debated issue both in the academic and politicaldecision making environment. Thus, in the context of favourable economic development, convergence assumes a process of closing the gap between the living standards between the poorer and richer areas beginning with the premise that the first have a swifter development as the latter. Considering this aspect, the present article analyses the trends of convergence/divergence at regional level in the context of the European Union with the help of GDP per capita and variation coefficients.

Keywords: territorial convergence; divergence; regional development; integration; Cohesion principle.

How to cite: Antonescu, D. (2020). Trends of Convergence at Regional Level in European Union (EU-28). In I.

Panagoreț \& G. Gorghiu (vol. ed.), Lumen Proceedings: Vol. 14. International Conference Innovative Business Management \& Global Entrepreneurship (IBMAGE 2020) (pp. 483-497). Iasi, Romania: LUMEN Publishing House.

https://doi.org/10.18662/lumproc/ibmage2020/35 


\section{Introduction}

Article 3 of the Treaty of the European Union refers to balanced development and achieving economic and social cohesion between the member states and their regions. Actually, this objective aimed right from the beginning a common area, where all member-states would benefit of the conditions and opportunities resulting from the Single Market Community.

The objective regarding cohesion is achieved by means of a convergence process that assumes diminishing territorial inequalities of any kind by financing projects in the regions where GDP per capita is lower than $75 \%$ of the Community's average. The cohesion process is not limited to the relatively poor regions, but aims also to more developed regions with the purpose of observing also the secondary effects for the entire EU (EC Report, 2013).

Identifying the convergence (divergence) trends is one of the intensely argued topics by both the academic and the political-decisional level [22]. The theoretical point of view regarding to the convergence was accompanied by models meant to mitigate the requirements of assessing over given periods the evolution of territorial inequalities (between countries or regions). Thus, in the context of the neoclassical theory, emerges for the first time the idea that under the conditions of economic growth territorial inequalities tend to diminish [24]. At the same time, other opinions were expressed that contradicted the neoclassical theory, respectively that the growth processes is cumulative over time and leads to increases in territorial inequalities [11; $14 ; 23 ; 28]$.

Considering the above-mentioned, the paper intends to analyses the evolution of territorial convergence (divergence) with the help of the variation coefficient (variance) and of the standard deviation within the EU28 over the period 2006-2017. This analysis will contribute to outlining a global, synthetic, image over the evolution of regional inequalities within the European Union and, indirectly, to developing the regional science and theory.

\section{State of the Art}

With roots in the theory of economic growth, regional convergence assumes a trend of territorial inequalities diminishment under certain conditions and over a certain period $[15 ; 16]$. The territorial convergence process began to show particular importance in the framework of the theoretical approaches by the beginning of the fifties, an importance that grew in time along with the expansion of the European Union. 
The studies and analyses regarding convergence consider also the way in which the factors involved in a certain process (integration, globalisation, etc.) act for diminishing inequalities between various territorial entities (countries, regions, influence areas, etc. ) [6;9; 10]. The idea that diminishing territorial inequalities assumes narrowing the values of the established performance indicators is unanimously agreed on [30;32].

In the specialised literature $[31 ; 34]$ three types of convergence, specific to some fields of application may be identified: (1) nominal convergence applied in the field of monetary policy and referring to obtaining economic stability and transition to the European Monetary Unit, (2) real convergence pursues to eliminate gaps in the development level between countries or regions as shown by the income per capita and labour productivity and (3) institutional convergence assumes compatibility from the viewpoint of institutions' structures and functioning.

Real convergence, in its turn, has two known forms: Beta-convergence and Sigma-convergence, which are relatively easy to compute (with the help of the regression coefficients and of the ones for variance/standard deviation).

1. Beta-convergence (B-convergence) aims to the process in which poor regions have higher increases than the rich ones and, thus, catchup with the latter. This convergence can be computed either in absolute or relative terms. Whenever the assumption is that all economies converge constantly towards the same level (in terms of GDP per capita and growth rates), we have a process of absolute Beta convergence. Nevertheless, the state of equilibrium depends on a series of characteristics specific to each economy, fact that determines a fluctuating process of convergence on long-term (GDP per capita depends on a series of determinant factors, such as factors' endowment, the quality of institutions, etc.), a process known as conditional Beta conditioned convergence. In the absolute Beta-convergence, in the wellknown model developed by Barro and Sala-i-Martin, the average increase rate of incomes between the year of reference 0 and $\mathrm{T}$ aims at the level of the initial income. If the dependence is significantly negative in this regression, then the process of absolute convergence is proven. The $B$ parameter based on which the regression slope can be derived captures the rate at which the regions get closer to the state of equilibrium. Very often, the half-life is used, that represents the period necessary for reducing the disparities to half. Usually, the convergence rate takes values around $2 \%$, which means a half-life of 28 years. The value by $2 \%$ of the convergence is often discovered as being a 
"natural constant" [1]. Additionally, the conditional convergence model includes control variables in order to account for the various initial conditions in the economies. The specialised literature regarding the convergence concludes that the "estimated speed of $\beta$-convergence is so similar in the data sets that we may use a general rule: economies converge with a yearly speed by $2 \% "$ " [5].

2. Sigma-convergence ( $\sigma$-convergence) have as premise that all regions tend towards the same level of regional output (towards a certain state of equilibrium), a fact that assumes the decline in regional inequalities under certain conditions of production. There are several methods of assessing sigma-convergence, from among which we mention: the variation coefficient, the Lorenzcurve, the Gini-index, the Atkinson-index, the Theil-index, the median logarithmic deviation. The sigma-convergence model analyses the variation level of the incomes per capita, but also for some other indicators, as well [16; 17]. This type of convergence occurs under the conditions of a $\beta$-convergence; however, this is not a sufficient condition for the emergence (the absolute $\beta$ convergence may be proved also without decreasing the incomes' dispersion [35].

Economies might reduce the gaps among them, yet random shocks push them outside or, in the case of conditional Beta-convergence, economies might shift towards various states of equilibrium.

Quah [35] and Friedman [29] suggest that $\sigma$-convergence is of higher interest because it shows the equitable way in which incomes can be distributed between regions.

While the absolute $\beta$-convergence model assumes that all regions converge towards the same value of constant state, the conditional model suggests that the equilibrium of regions is determined by the initial values of the variables. Nevertheless, the areas have different structural characteristics used in the conditional $\beta$-convergence framework, and the regions converge towards different equilibrium states $[12 ; 13 ; 18]$.

This duality of the $\beta$-convergence model is often criticised [33]. Thus, a new concept is launched - the Convergence club. In the neoclassic theory, the Convergence club emerges when the rate of savings from wages is higher than the rate of savings from capital [24]. A classic model of the Convergence club has as basis the local indicators of spatial association (LISA), with the purpose of detecting some groups of countries that converge in the same way. The statistics allow for identifying the groups of neighbouring regions with average values of the geo-referential variable 
("hot spots") or with a low spatial concentration of the $\mathrm{x}$ values ("cold spots"). A geographic configuration stable over time is a clear $\beta$-convergence barometer.

The econometric models applicable to the convergence process can be tested empirically and they support the economic theories: the neoclassical approach promotes the idea of a convergence process as outcome of diminishing the marginal costs of capital, whereas the postKeynesian theories consider that on long-term, polarisation emphasises the inequalities between rich and poor regions [19; 20; 25; 26; 27].

Regarding $\sigma$-convergence, analyses resort to standard deviation for the GDP per capita indicator and, sometimes to the variation coefficient. The results obtained in these studies are presented in the following $[2 ; 7 ; 8$; 21; 36; 37; 39]:

Boldrin/Canova (2001) find a decrease of the variation coefficient for certain indicators at EU-15 level over the period 1980-1996.

$\square$ Yin/Zestos/Michelis (2003) proved the existence of a $\sigma$ convergence in the period 1960-1995, for EU-6, EU-9, EU-12 and EU-15 10 .

- Tondl (2001) - shows the inexistence of $\sigma$ convergence over the period 1975-1994 for EU-9.

- Neven/Gouyette (1994) notice that over the period 1975-1990, $\sigma$ convergence is non-existent for EU-9.

- Neven (1995) - shows that $\sigma$-convergence is not proven for 107 NUTS-2 regions over the period 1975-1989. At the same time, López-Bazo et al. (1999) show the inexistence of $\sigma$-convergence over the period 19811992 for EU-12. And Barrios/Strobl (2005) prove that the standard deviation changed very little over the period 1975-2000, for EU-15.

- Cappelen et al. (2003b) cannot find $\sigma$-convergence over the period 1980-1997 for EU-9 and EU-12. Moreover, Basile/de Nardis/Girardi (2005) cannot identify $\sigma$-convergence for EU-12 over the period 1975-1998.

- Paas/Schlitte (2006) highlight $\sigma$-convergence for EU-25 over the period 1995-2003.

- Simionescu M. (2014) assesses $\sigma$-convergence for EU-28 based on the standard deviation and on the variation coefficient for GDP per capita (PPS), based on two methods (standard and the method using the population) for the period 2000-2012 [38]. The findings show that the variation degree decreased but economic convergence cannot be confirmed as the variation coefficient is higher than $40 \%$ (for both methods). Nonetheless, the weighted method suggested an improvement of the convergence process. The dynamic analysis of real expenditures (PPS) showed that over the period 2000-2012 a low variation degree was found for 
GDP per capita (PPS) within EU-28, which means that a relative convergence process occurs.

Albu L.L. and Marcu N. in their paper Macroeconomic and regional convergence computed the average values and the variation coefficient (the dynamics in absolute terms) for GDP per capita at EU-28 level, for the 276 NUTS-2 regions over the period [3; 4]. The results have identified four quadrants (numbered in trigonometric sense from I to IV) shaped by states and regions, as follows:

- quadrant I - comprises the states that improved their position against the European average, but where a divergence process was registered between the own regions of a country (here are included all Eastern states and Ireland);

- quadrant II - states with the most unfavourable dynamics and worsening trends regarding their position against the European average, as they record a divergence process between the regions;

-quadrant III - comprises the states for which a worsening of their position was registered against the European average, however, at domestic level a convergence process was achieved between the regions;

- quadrant IV - includes only Germany as it records the most favourable dynamics, concomitantly with an improvement in position against the European average and simultaneously with a convergence process between the regions.

At the same time, the conclusions of the study have shown two rules as part of the general convergence process:

a) if a country or a group of countries is placed regarding GDP per capita on a left-side position, far from the European average, it is expected that they will show a rapid increase in the level of this indicator concomitantly, nonetheless, with displaying a relatively strong divergence between the own regions;

b) if a country or group of countries is placed on the right-side of the average European level a slower economic growth is expected concomitantly with a slight trend of divergence between own regions, disrupted possibly by temporary spells of convergence.

Irrespective of the period of reference and the number of analysed regions, the majority of the reviewed studies have not found the existence of $\sigma$-convergence at territorial level within the European Union, but rather a divergence process regarding the evolution of GDP per capita. 


\section{Aims of the Research}

In the context of favourable economic development, convergence assumes a process of closing the gap between the living standards between the poorer and richer areas beginning with the premise that the first have a swifter development as the latter. Considering this aspect, the present article analyses the trends of regional convergence in the context of the European Union with the help of GDP per capita, variation coefficients and Histogram.

\section{Research Methods}

Article follows the analyses based on Sigma-convergence ( $\sigma$ convergence - standard deviation) and on the premise that all regions tend towards the same level of regional income/output (towards a certain state of equilibrium), a fact that assumes the decline in regional inequalities under certain conditions of production. The main methods of assessing sigmaconvergence are the coefficient of variation, also Histogram.

\section{Findings}

\subsection{The results of applying the $\sigma$-convergence model}

The present chapter aims to present of results of territorial convergence at the level of the 276 NUTS 2 regions (EU-28). The general framework of analysis is based on the statistical and planning NUTS 2 regions, the unitary system regulated within the European Union by the Eurostat Statistical Directorate.

From the viewpoint of the applied methodology, in order to assess the hypothesis of the presence of a convergence (divergence) process at the level of the NUTS-2 regions the variation coefficient (sigma-convergence) will be used next to the maximum/minimum values and histograms. This coefficient will evaluate the dispersion degree of the regional incomes, incomes as expressed with the help of the GDP per capita (indicator PPS). The period of the analysis is 2006-2017 and the data source is the Eurostat database.

\subsection{Regional convergence analysis}

The global image of the total GDP development at EU-28 level (PPS) shows that the financial and economic crisis phenomenon triggered in the year 2008 has impacted on the EU economy, and on the one of the member-states by triggering severe recession as of 2009, followed subsequently by unequal recovery or resilience [40]. 
Thus, the growth rates for total real GDP (PPS) reduced considerably in the year 2009 at EU-28 level by -4,3\%. The turnaround occurred gradually. Accordingly, in 2010, the growth rate of total real GDP was by $+2.1 \%$ and it slowed down to $1.8 \%$ in 2011 . The year 2012 brings with it a new decrease by $-0.4 \%$, and subsequently positive rates of growth are registered progressively: in 2013 by $+0.3 \%$, in 2014 by $1.7 \%$, and in 2015 , an increase by $+2.3 \%$. In the year 2016, growth continued, but at a lower rate $(1.9 \%$ ), and in the year 2017, GDP increased by $2.4 \%$ (the highest annual growth rate as of the beginning of the crisis)

At the level of the member-states in 2017, is found that the highest annual real GDP growth rates were in countries with economies regarded as medium to small (as is the case for Ireland recording a growth by $7.2 \%$, Romania by $+6.9 \%$, Malta by $+6.4 \%$ ). At the same time, developed economies registered lower growth rates (the lowest variation rates were recorded in Belgium and the United Kingdom - both by $+1.7 \%$; Italy with a growth by $+1.5 \%$, and Greece by $+1.4 \%$ )

Regarding territorial convergence, it is found that during the first year of the economic crisis the coefficient of variation for GDP per capita underwent a decrease from 0.465 in 2007 to 0.461 in 2008, and it continued decreasing also in 2009 to 0.460 . In both instances, a value by $0.46 \%$ of the coefficient of variation shows that there is a higher concentration of real incomes as expressed by GDP per capita at regional level, more specifically a territorial economic divergence process with some minor fluctuations from one year to the other, but with a clear evolution towards the latter. Practically, territorial convergence is not supported by the value of the variation coefficient computed for the level of the 276 NUTS 2 regions.

The analysis of territorial convergence within EU-28 over the entire analysed period, 2006-2011, is presented in the following based on the average values, on maximum/minimum values, and based on the coefficient of variation (sigma-convergence). The outcome are presented in the following:

- Over the period 2006-2017, the average value for GDP per capita increased from 24127.3 Euro/inhabitant to 28694.6 Euro/inhabitant, which is a growth by $18.9 \%$.

- In the year 2006, the number of regions above the Community average was by 131 (47.46\% from total); in the year 2017, the number of regions above average decreased to $115(41.67 \%)$.

- The number of regions below average was in 2006 of $145(52.4 \%$ from total), and increasing to 159 (57.61\%).

- An imbalance trend is present at regional level, given by the decrease in the numbers of very rich regions (over $75 \%$ from average) - 
from 213 to 204 (2006 vs. 2017) and an increase in the number of regions below $75 \%$ from the Community average, from 63 to 74 .

- The minimum value increased by $55 \%$, while the maximum value increased by $37 \%$, and the average registered an increase by $61.85 \%$.

- An increase is found in the number of very rich regions (with a GDP per capita over $90 \%$ of the Community average), from 176 NUTS 2 regions in 2006 to 191 NUTS 2 regions in 2017.

- The coefficient of variation shows a slight increasing trend, from $0.46 \%$ to $0.49 \%$. Its value is increased showing a divergence trend (Table 1 ).

Table 1: Average, maximum and minimum values, coefficient of variation - GDP per capita (PPS) (Euro per capita, no., \%)

\begin{tabular}{llll}
\hline & 2006 & 2008 & 2017 \\
\hline Mean (Euro/capita) & 24127.34 & 25365.11 & 28694.6 \\
No. Reg. above average & 131 & 123 & 115 \\
\% of Reg. above average & 47.5 & 44.6 & 41.7 \\
$\begin{array}{l}\text { No. Reg. below average } \\
\text { \% of Reg. Below average }\end{array}$ & 145 & 153 & 150 \\
$\begin{array}{l}\text { No. Reg. over 75\% from } \\
\text { average }\end{array}$ & 213 & 55.43 & 57.61 \\
$\begin{array}{l}\text { No. Reg. below 75\% from } \\
\text { average }\end{array}$ & 63 & 67 & 204 \\
$\begin{array}{l}\text { Minimum Value } \\
\text { Maximum Value }\end{array}$ & 6000 & 7000 & 74 \\
$\begin{array}{l}\text { Coefficient of Variation } \\
\text { Sorce Own conpt }\end{array}$ & 0.46 & 147,500 & 9300 \\
\hline
\end{tabular}

Source: Own computation, Eurostat Data, https://ec.europa.eu/eurostat/databrowser/ view/nama 10r_2gdp/default/table?lang=en [41]

Regarding regional convergence (sigma convergence), the value of the coefficient of variation shows a slight increasing trend (regional divergence), as it records close values for the two analysed years (0.46 in 2006 and 0.49 in 2017). At the same time, from the analysis is found that the maximum value increased by $37.73 \%$, the minimum value increased by $55 \%$, and the average an increase by $61.85 \%$. 


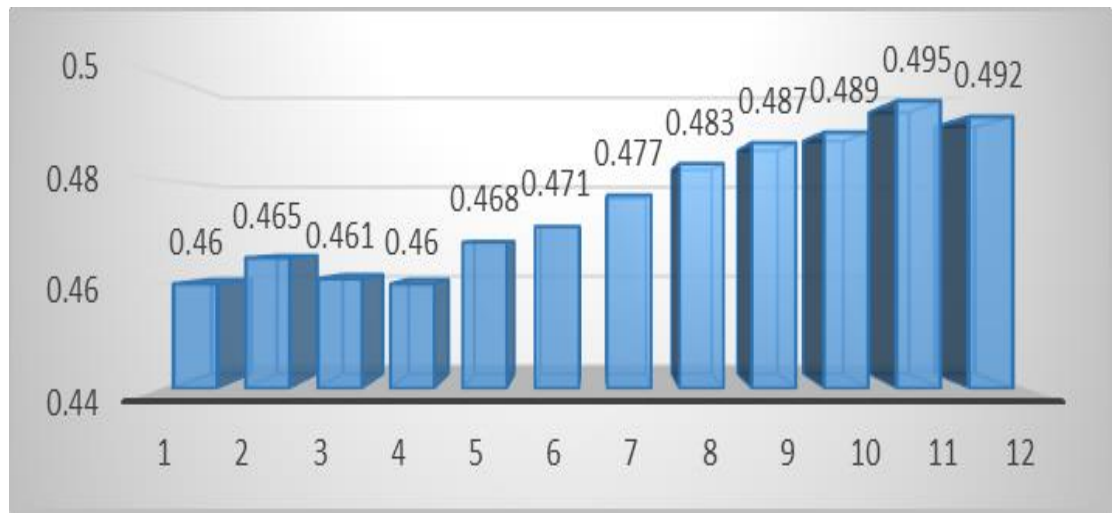

Figure 1: GDP per capita at regional level, EU-28 - variation coefficient, 20062017 period

Source: Own computation, Eurostat Data. https://ec.europa.eu/eurostat/databrowser/ view/nama $10 \mathrm{r}$ 2 $\mathrm{gdp} /$ default/table?lang=en [41]

At the same time, the difference decreased between the maximum and minimum value from a ratio by 23:1 to 20:1 over the period 2006-2017, by over 2 pp. Moreover, it is noticeable that over the crisis period, the differences between the two values decreased to 20:1, following a close fluctuating evolution (after three years of growth follows one year of decrease).

Based on the analysis of the histograms realised for the two years of the interval 2006 and 2017, is noticeable a trend of increased differences in

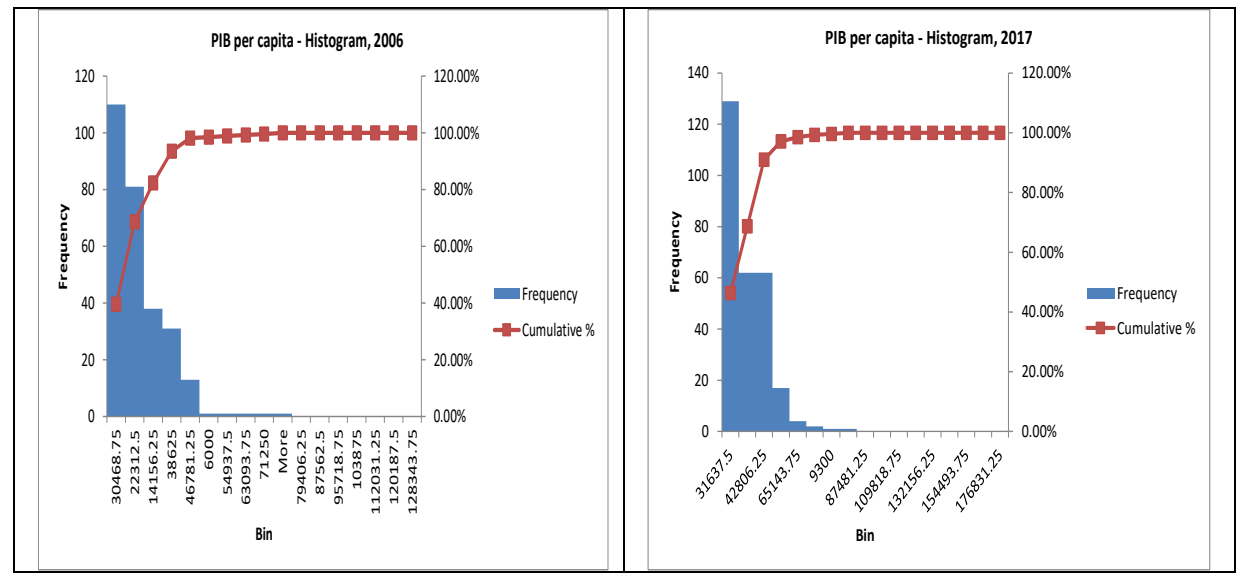

Figure 2: Histogram, GDP per capita, Eurost data Source: Own computation, Eurostat Data. https://ec.europa.eu/eurostat/databrowser/ view/nama $10 \mathrm{r} 2 \mathrm{gdp} /$ default/table?lang=en [41] 
As result of the calculations realised at regional level within EU-28, a process of divergence was identified over the period 2006-2017.

\section{Conclusions}

In order to promote suitable initiatives and for evaluating their efficiency in achieving the convergence goal are required studies and analyses that attest for the convergence/divergence trends and dynamics for both member-states and between the regions. This fact justifies also the common concern as regards the evaluation of the process in itself. Thus, it is important to know about the trends that might indicate an improvement in the living conditions of the inhabitants or, to the contrary, account for increased inequalities between various areas and states (a situation in which adequate measures should be taken at community and national level).

A process of territorial convergence is considered as a barometer of some positive impact of the regional cohesion and development policy on the evolution of the inequalities between various areas and communities.

The present paper attempted to highlight the theories and most frequent employed methods and instruments for measuring convergence and economic inequalities at regional level. The results identified in various specialised papers and those obtained from our own calculations are qualitatively similar.

The main conclusion of the present paper is that over the period 2006-2017, within the EU-28, an economic process of divergence was recorded, a process of more marked inequalities between the regions. Thus, the level of the regional inequalities expressed with the help of the variation coefficient is high, and with an increasing trend (from $0.46 \%$ to $0.49 \%$ ). This aspect should be considered as relevant for the decision-factors at community level, adequate and targeted measures being required for achieving the territorial cohesion objective (supporting more the regions left behind from the viewpoint of development, identifying and putting to good use the regional endogenous potential, promoting regions of knowledge, etc.). At the same time, the relevance for the factors involved is that pursuing regional inequalities and in monitoring their evolution is, with certainty, of strategic importance and significant for designing and managing new regional policies over the period 2021-2027.

\section{References}

[1] Abreu M, de Groot HL, Florax RJ. Space and Growth: A Survey of Empirical Evidence and Methods. Region et Developpement [Internet]. 2005 [cited 2020 
Oct 15]; 21:13-44. Available from:

https://econpapers.repec.org/article/toujournl/v 3a21 3ay 3a2005 3ap 3a1 $\underline{3-44 . h t m}$

[2] Aiginger K, Falk M. Explaining Differences in Economic Growth among OECD Countries. Empirica [Internet]. 2005 [cited 2020 Oct 15];32(1):19-43 Available from: https://doi.org/10.1007/s10663-005-1977-7

[3] Albu LL, Marcu N. Convergența macroeconomică şi regională [Internet]. Bucuresti: Institutul National de Cercetări Economice; 2018 [cited 2020 Oct 15]. 16 pages. Available from: http://www.studiieconomice.ro/2018/seince181214.pdf

[4] Albu LL. Structural convergence in European Union. Annals of the Constantin Brâncuşi University of Târgu Jiu, Economy Series [Internet]. 2012 [cited 2020 Oct 15]; 2(4):1-11. Available from: https://www.utgjiu.ro/revista/ec/pdf/201204.II/1_Albu\%20Liviu\%20Lucian.pdf

[5] Allington NF, McCombie JS. Economic growth and beta-convergence in the East European transition economies. Economic Growth: New Directions in Theory and Policy [Internet]. 2007 [cited 2020 Oct 15]; pp. 200-222. Available from:

https://www.researchgate.net/publication/288391350 Economic growth an d beta-convergence in the East European transition economies

[6] Anselin L. Spatial Econometrics. Methods and Models. Dordrecht, Boston, London: Kluwer Academic Publisher; 1998. 295 pages.

[7] Armstrong HW. Convergence among Regions of the European Union 19501990. Papers in Regional Science [Internet]. 1995 [cited 2020 Oct 15];74:143152. Available from: https://doi.org/10.1111/j.1435-5597.1995.tb00633.x

[8] Armstrong HW. European Union Regional Policy: Reconciling the Convergence and Evaluation Evidence. In: Cuadrado-Roura JR, Parellada M, editors. Regional Convergence in the European Union. Advances in Spatial Science [Internet]. Berlin, Heidelberg: Springer. 2002 [cited 2020 Oct 15]; pp. 231-272. Available from: https://doi.org/10.1007/978-3-662-04788-0 11

[9] Antonescu D. Identificarea disparităţilor şi convergenței economice regionale în UE şi în România [Internet]. Bucuresti: Institutul National de Cercetări Economice; 2012 [cited 2020 Oct 15]. 50 pages. Available from: http://www.studii-economice.ro/2012/seince120528.pdf

[10] Antonescu D. Politica de dezvoltare regională a României în etapa postaderare [Internet]. Bucuresti: Institutul National de Cercetări Economice; 2013 [cited 2020 Oct 15]. 160 pages. Available from: http://www.studiieconomice.ro/2013/seince130516.pdf

[11] Aghion P, Howitt P. Endogenous Growth Theory. Cambridge, MA: MIT Press; 1998. 694 pages. 
[12] Aydalot P. Dynamique spatiale et développement inégal. Paris: Economica; 1976. 354 pages.

[13] Aydalot P. Economie régionale et urbaine. Paris: Collection Economie; 1985. 487 pages.

[14] Atkinson AB. On the measurement of economic inequality. Journal of Economic Theory [Internet]. 1970 [cited 2020 Oct 13];2(3):244-263. Available from: https://doi.org/10.1016/0022-0531(70)90039-6

[15] Barro RJ, Sala-i-Martin X, Convergence. Journal of Political Economy [Internet]. 1992 [cited 2020 Oct 13];100(2):223-251. Available from: https://doi.org/10.1086/261816

[16] Barro R, Sala-i-Martin X. Technology Diffusion, Convergence and Growth. Journal of Economic Growth [nternet]. 1997[cited 2020 Oct 13];2(1):1-27. Available from: https://doi.org/10.1023/A:1009746629269

[17] Barro RJ, Sala-i-Marti X. Economic Growth and Convergence across the United States. Working Paper Series of the National Bureau of Economic Research [Internet]. 1990[cited 2020 Oct 13], 3419. Available from: https://doi.org/10.3386/w3419

[18] Basile R, de Nardis S, Girardi A. Regional Inequalities and Cohesion Policies in the European Union. Rome: ISAE Istituto di Studi e Analisi Economica [Internet]. 2005[cited 2020 Oct 13]; Paper No. 23. Available from: http://dx.doi.org/10.2139/ssrn.936319

[19] Capello R, Nijkamp P. Regional growth and development theories revisited. Faculteit der Economische Wetenschappen en Bedrijfskunde [nternet]. 2009 [cited 2020 Oct 13]; 2009-22. Available from: https://research.vu.nl/en/publications/regional-growth-and-developmenttheories-revisited-2

[20] Carrington, A. Regional Convergence, Polarisation and Mobility in the European Union - , 2006, International Regional Science Review, 29, pp. 6480, https://doi.org/10.1177/0160017605279456, https://journals.sagepub.com/doi/10.1177/0160017605279456.

[21] Cheshire P, Carbonaro G. Convergence - Divergence in Regional Growth Rates. An Empty Black Box?. In: Vickerman RW, Armstrong HW, editors. Convergence and Divergence among European Regions. London: Pion; 1995. pp. 89-111.

[22] Constantin DL. Elemente de analiză şi previziune regională şi urbană. Bucureşti: Editura Oscar Print; 1998. 121 pages.

[23] Da Silva MA. Aghion and Howitt's Basic Schumpeterian Model of Growth Through Creative Destruction: A Geometric Interpretation. SSRN Electronic Journal 2011 [nternet]. 2010 Dec 20[cited 2020 Oct 13]; Available from: http://dx.doi.org/10.2139/ssrn.1756244 
[24] Dalgaard CJ. The Rate of Convergence in the Solow model and then some. Institute of Economics, University of Copenhagen [nternet]. 2005 Feb 10 [cited 2020 Oct 13]; Available from: https://web2.econ.ku.dk/dalgaard/growth/Growth05/Noter/Note2_solowm rw.pdf

[25] Dăianu D. Convergența economică. Cerințe şi posibilităţi. In Iancu A, coord. Dezvoltarea economică a României. Competitivitatea şi integrarea în Uniunea Europeană. Bucureşti: Editura Academiei Române. 2003, https://academiaromana.ro/carti/carti2004/pag carte aiancu.htm

[26] Eckey HF, Döring T, Türck M. Convergence of Regions from 23 EU Member State. Kassel: Volkswirtschaftliche Diskussionsbeiträge, Universität Kassel [Internet]; 2006[cited 2020 Oct 13]; 36 pages. No.: 86. Available from: http://hdl.handle.net/10419/32129

[27] Eckey HF, Dreger C, Türck M. Convergence of Regions from 23 EU Member State. Berlin: German Institute for Economic Research [Internet]; 2006[cited 2020 Oct 13]; 28 pages. No.: 631. Available from: https://www.econstor.eu/bitstream/10419/18524/1/dp631.pdf

[28] Fujita M. Thünen and the New Economic Geography 2011. Japan: Research Institute of Economy, Trade and Industry [Internet]; 2011 Nov[cited 2020 Oct 13]; 20 pages. Discussion papers No.: 11074 Available from: https://guides.lib.monash.edu/ld.php?content id=14570618

[29] Dostaler G. Friedman and Keynes: divergences and convergences. The European Journal of the History of Economic Thought[Internet]; 1998[cited 2020 Oct 13];5(2):317-347 Available from: http://dx.doi.org/10.1080/10427719800000023

[30] Krugman P. Geography and Trade. MIT Press, Cambridge (MA): MIT Press. ISBN 0-262-11159-4, 1991

[31] Iancu A. Problema convergenței economice, 2009, Probleme ale integrării economice, Oeconomica, Online ISSN 2286-0266, Print ISSN 1223-0685, http://oeconomica.org.ro/files/pdf/93.pdf.

[32] Isard W. Methods of Regional Analysis; an Introduction to Regional Science Cambridge: Published jointly by the Technology Press of the Massachusetts Institute of Technology and Wiley, New York, 1960.

[33] Le Gallo, Cem E. Exploratory spatial data analysis of the distribution of regional per capita GDP in Europe, 1980-1995. Papers in Regional Science [Internet]. 2005 Jan 14[cited 2020 Oct 13];2003(82):175-201. Available from: https://doi.org/10.1111/j.1435-5597.2003.tb00010.x

[34] Lucas RE. On the mechanics of economic development. Journal of Monetary of Economics[Internet]. 1998[cited 2020 Oct 13];22(1):3-42. Available from: https://doi.org/10.1016/0304-3932(88)90168-7 
[35] Quah T. Empirics for economic growth and convergence. European Economic Review[Internet]. 1996 Jun [cited 2020 Oct 13];40(6):1353-1375 Available from: https://doi.org/10.1016/0014-2921(95)00051-8

[36] Monfort P. Convergence of EU regions. Measures and evolution. European Union. Regional Policy[Internet]; 2008[cited 2020 Oct 13]. 20 pages. Working Papers No.: 1. Available from:

https://ec.europa.eu/regional policy/sources/docgener/work/200801 conve rgence.pdf

[37] Romer P. Endogenous Technological Change. Journal of Political Economy[Internet]. 1990[cited 2020 Oct 13];98(5):S71-102. Available from: https://doi.org/https://doi.org/10.1086/261725

[38] Simionescu M. The Intensity of Convergence Process in the European Union. Economic Analysis. 2014. 47(1-2):103-110.

[39] Terrasi M. Convergence and divergence across Italian regions. The Annals of Regional Science[Internet]. 1999 [cited 2020 Oct 13]; 33:491-510. Available from: https://doi.org/10.1007/s001680050117

[40] Zaman G, Georgescu G, Goschin Z, Antonescu D, Popa F. Dezvoltarea economică endogenă la nivel regional. Cazul României [Internet]. Bucuresti: Editura Expert. 2015[cited 2020 Oct 13]; 330 pages. Available from: https://doi.org/10.13140/RG.2.1.2731.4000

[41] Eurostat Data [Internet]. [cited 2020 Oct 13]. Available from: Eurostat, https://ec.europa.eu/eurostat/databrowser/view/nama 10r_2gdp/default/ta ble?lang $=$ en 